\title{
TALENT MANAGEMENT IN HIGHER EDUCATION - A CASE STUDY FROM HUNGARY
}

\author{
Katalin Takács-György*, István Takács**
}

\begin{abstract}
Background. There is a lot of debate on the role of higher education in the context of intellectuals. Many of them agree as to the question of importance and talent management. Experiences, the students gained during their studies are also key factors for the next generation, this is frequently mentioned in literature of leadership, organisational culture not depending on business or non-governmental organisations. More and more importance goes to an individual, problem solving employee, a human resource that is responsible for new ideas, creating new value is critical. In the modern, developed (successful) economies higher share of value added goes back to knowledge (not to materialised resources or capital), so "people are the main source". A paradigm change took part in leadership: leaders must be problem solving ones who recline upon the problem solving individuals.
\end{abstract}

Research aims. The aim of this study is to show an example how higher education can meet the expectations of organisations in the context of knowledge based economy, with supporting students' scientific research work.

Methodology. Based on secondary sources, with content analysis the history of the Hungarian Students' Research Societies movement is introduced. To show the development of Students' Research Societies statistical data were used.

Key findings. Talent management is one of the tasks of higher education, but to define what is talent and what will be a good output of higher education is not too easy. New, competence based educational methods, team-oriented, problem solving project works are needed instead of learn-the-data education, to meet the changed requirements of business and public organisations.

The unique, Hungarian Students' Research Societies movement meets these requirements of talent management. To be successful, at the very beginning of students' studies a teachers - students' relationship (trust!) must be developed. What can the student - tutor cooperation, work in scientific society be compared to? To the ancient Greek philosophers, to Aristotle and his school-masters' mates.

\footnotetext{
* Óbuda University - Budapest, Hungary. E-mail: takacsnegyorgy.katalin@kgk. uni-obuda.ku

** Óbuda University - Budapest, Hungary. E-mail: takacs.istvan@kgk.uni-obuda.ku
} 
When walking on the hill surrounded by his disciples, they discussed scientific, philosophical, political questions or arts, they were equal on the same floor, questions were answered and disciples were introduced into the world of life.

By the case study of the unique Students' Scientific Research Societies, it has been concluded that besides the good research works, thesis, the main result is that by taking part in the scientific work, the students are able to believe: "we are the best".

Keywords: talent, knowledge, needs, organisation, students' research, Hungarian movement.

\section{INTRODUCTION}

The role of knowledge in learning organisations, the increasing importance of invisible values are beyond dispute in nowadays management sciences. Lots of changes have taken part in higher education in the last decades. After the increase of the number of entering students into higher education - meeting the aim of the European Union to reach over $30 \%$ of the age 35-40 having a degree in higher education - an increased number of universities, faculties, a radical drop and serious financial problems occurred. The mass education, the less motivated, tired teaching staff faced with the loss of personal education, the changed (organisational) requirements of the market. New educational methods, new ways of work, new or renewed talent management methods should be applied in higher education.

Aristotle, the Greek philosopher, established the Lükeion, "The Lyceum" - a Peripatetic school - in Athens, in 335 B.C., and gathered a great library. After his return from Asia, Aristotle began teaching regularly in the morning in the Lyceum. After the morning lessons, Aristotle would frequently lecture on the grounds for the public and manuscripts of his compiled lectures were eventually circulated. The personal contact, conversations, disputation of the philosophical, scientific, and political questions characterized the teaching way. Some of his schools' criteria survived and was a practice in the education of medieval universities, like regularly organised disputes, personal conversations during the lectures, the attention paid to students' opinions (not only on knowledge). The system allowed to find the most talented students (Lyceum, Wikipedia). Successful talent management requires an "Aristotle, the professor" and a curious, willing to learn, juvenile. If either is missing it makes the endeavour of the other unattainable. 
This study attempts from the above-mentioned idea to try to define the needs of knowledge based economy, the changed requirements of organisations towards entering human resource, to identify some potential way of talent management. Despite the radical changes, which have taken place in (Hungarian) higher education in the last decades, a special way, the Students' Scientific Research Societies survived and opens a special platform for talented students to enter into the scientific, academic, or business world. The theme of the paper is a case study, the introduction of the movement based on content analyses. The study has concluded "the model works under changes" and about $5-35 \%$ of the students got costumed with scientific research work over their compulsory studies and being a participant of students' research societies helps them to believe: "we are the best".

\section{Knowledge based economy}

Bell (1973) stated three predictions on the future development connected with the role of universities at that time - after the new wave of youth - under an emerging, changing society and economy. First was about the change of human capital (knowledge) instead of capital (finance) as the main resource of economy, development in the industrial societies. The next statement was about the appearance of intellectual technologies (supported by IT), more importance of the social environment, social movements instead of the cost-based, profit oriented thinking in economy as the main characteristics of post-industrial societies.

During the last half century, the former mentioned changes have not taken place exactly. Universities really got higher importance in increasing the human capital at all, economy turned into the direction of 'information economy' and only those are able to be real participants of economy, who are creative, who are able to give answers to the changing world (environment), to make good and appropriate decisions. The role of human resource in economy changed, instead of the former, encyclopaedical (thesauri) mechanical knowledge the creative knowledge came into the fore, as a pre-requirement of the knowledge-based economy and learning society.

Drucker (1969) also highlighted the predicted changes into the direction of knowledge-based economy from economy based on material goods and capital. If we have a look on the GDP structures of developed 
countries, a radical increase in the share of tertiary sector at the expense of primer sector (i.e. mining, agriculture) and industry (second sector) can be observed. Not to go deeply into the issue of information society, it should be highlighted that the role of information (how we create, distribute, use, integrate the manipulation of information and the techniques) became really an economic power.

What is knowledge economy and what kind of people are needed? The knowledge economy is the use of knowledge in order to generate tangible and intangible values not only for the economy, but for society as well. As the role of mechanisation increased over the $20^{\text {th }}$ century, technical development precipitates the physical human labour and the human capital and managerial skills are needed. Technology and in particular knowledge technology help to transform a part of human knowledge to machines. This knowledge can be used by decision support systems in various fields and generate economic value. For business entities, human capital belongs to the group of invisible assets. Not going deeply into the issue here, it must be added that a loyal human capital is better.

"Knowledge" of an organisation, the way how they are able to "use" the human capital, the way makes them different from each other. All the 'good' organisations want to employ the best ones, but the question is: Who are they?

\section{Revolution in the word of organisation (since the 1970s)}

The human capital - knowledge, skills, and willingness to do something (i.e. loyalty) - besides information and network, is one of the key factors in business in these days. To gain success in economy every organisation has to discover the most important attributes of their, individual human resource in the context of the needs. Several scientists and 'gurus' of management have dealt with the reasons of changes of human resources in organisations. Here we mention Chester Barnard (1938), who based on his early works, defined organisations as systems of cooperation of human activity, changing continuously, where - as the people are individuals - the management should focus not only on the technical processes, but also work organisation. It is important that the individual stakeholders join to the organisation in order to reach their individual goals. According to him, the efficiency of an organisation depends on the degree to which that organisation is able to satisfy the motives of the individuals. If an organisation satisfies the 
motives of its members while attaining its explicit goals, cooperation among its members will last. Better is the satisfaction of individuals longer than an organisation exists.

He differentiated the following functions of the executive:

1. Establishing and maintaining a system of communication.

2. Securing essential services from other members.

3. Formulating organisational purposes and objectives.

4. Managing people and making sure they do their jobs.

If we accept these four basic tasks of managers, we also accept the importance of inner communication of the stakeholders, clear declaration of the decision making and the question of responsibility and the role of motivation for better work. It also shows the direction of the future: the role of human resource will change.

The typical characteristics of the internal stakeholder from the point of view of their behaviour and attitudes to being a better, more loyal employee can be summarised. One's character can be considered as a mature one if it changed to independency and activity from dependence and passivity. This appears in the range of interests and in keeping a check on individual activity (Argyris, 1966). Freedom of taking liability instead of riddance of liability is characteristic (Fromm, 1993).

Hersey et al. (1996) introduced "Readiness" (R) for the maturity and differentiated two main factors: Ability (as skill - what and how a person is able to do) and Willingness (as will - what the person wants to do). They distinguished for levels of maturity of their model based on the above-mentioned factors:

"Readiness level 1 (R1): Unable and unwilling (insecure). The follower is unable and lacks commitment and motivation (and confidence).

Readiness 2 (R2): Unable but willing (confident). The follower lacks ability, but is motivated and makes an effort (and is confident as long as the leader is there to provide guidance).

Readiness 3 (R3): Able but unwilling (insecure). The follower has the ability to perform the task, but not willing to use that ability (and is insecure to or apprehensive about doing it alone).

Readiness 4 (R4): Able and willing (confident). The follower has the ability to perform and is committed (and is confident about doing it) (Hersey at al., 1996; Bakacsi, 2015a).

Based on their theory, willingness has got wider interpretation, willingness is not only simple motivation, but commitment to the organisation (see confidence and insecure), too. From the point of view 
of higher education, willingness means one interesting point. To help the students to be interested in science, in more activities beyond the compulsory studies is a task for the teaching staff. The question is how to make the students willing to spend time, energy, a lot of work instead of "student life". If they see the success of their schoolmates more they are willing to be on the job. The Hungarian example will show one, but not the only one - way for it.

The role of human resource went through radical changes in the $20^{\text {th }}$ century. The human resource that is responsible for new ideas, creating new value and wishing to take part in the decision-making processes is critical. They want to be well informed and responsibility is getting more important for them (see Maslow, Aldefer and Herzberg motivation theories). As people are different with different skills, their motivations vary and their loyalty is different, too. More and more importance goes to an individual, problem solving employee, the role of invisible assets are increased: "people is the main source". The first is talent ("value creation") in the focus of modern management. The so-called soft factors have got higher importance in management, the team spirit, the delegation of decisions, more communicative leaders, changes in motivation tools, the question of corporate social responsibility, increase propensity for win-win strategy, along mutual advantages, both are factors to take into consideration when an organisation selects a future human resource (Kránitz, 2012; Konczosné Szombathelyi, 2012; Bakacsi, 2015b; Cziráki, 2015).

In the changing business environment knowledge management has become critically important from the point of view of adaptability of companies and staying competitive. Based on an international survey carried out by $\mathrm{PwC}$ in 2016, the interviewed Hungarian executive directors answered that the most important skills were problem solving, ability to cooperate, adaptive, creative, and innovative factors (Figure 1).

The role of creativity in the business is mentioned frequently. Creativity is connected with innovation. As the base of creativity is talent, talent management should take the business expectation at the same time (Derecskei, 2012). However, creativity in education means not only "the result of the teaching process", but teaching itself. As the teacher is somehow the moderator of the students, her/ his role in education is very important. Kolnhofer-Derecskei (2016) measured and summarised environmental factors, which can foster 
or on the contrary inhibit organisational creativity. She found that the perceived effects of leadership styles on organisational creativity showed a quite strong and significant connection in Hungary. The democratic style was perceived as stimulating, while the authoritarian style was regarded as inhibitory, and the laissez-faire style did not have an effect. In case of a university it means that the teaching and coaching styles of mentors/teachers also influence the success of talent management. This style is the teachers' behaviour perceived by the students, but it is not a playable role, it is shaded by both personality characteristics and group dynamic effects. Also important is how the connection between the teacher and the students looks like. If it is based on parity, on respect of each other (the connection is syndetic) the willingness of the students will be stronger to take part in research activities (and in community activities, too). Besides this, the given task, organisation, and culture, not to mention ethical perspectives, should be kept in mind.

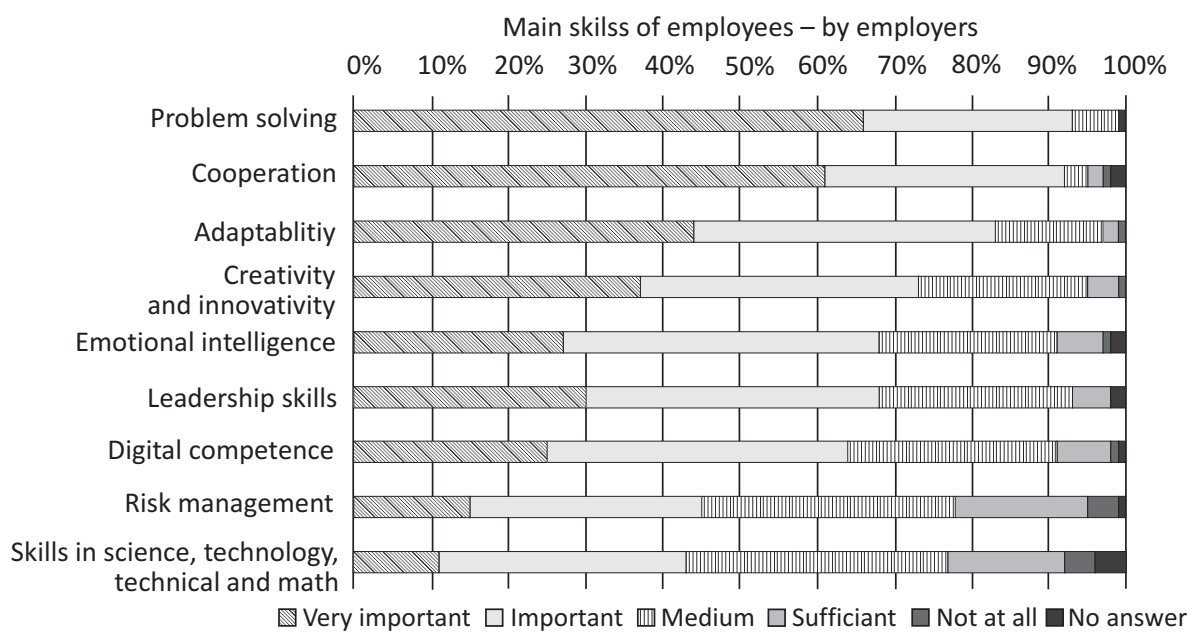

Figure 1. The required main skills of employees - by employers in Hungary, 2016

Source: based on the data of PwC (2017), among 186 chief executive directors, in Hungary.

If we take into consideration the revolution in the organisation life (since the 1970s), the changes of needed skills, the changes in motivation (aims, tools, etc.), the new concept of managerial skills, the changed role of education and teachers must be highlighted. From 
our point of view higher education is very important, where one of the main questions is: how to find, discover the talent, how to find in which areas, skills they are talented and finally how to help the students believe that they are talented and they can solve a problem, they can do it.

\section{Is knowledge management $\neq$ talent management?}

Not going deeply into the issues of knowledge management the main tasks of it are the following: identification, creation, accumulation, and application of the knowledge inside and between the organisations. Each, above mentioned tasks of knowledge management belong to the human capital, in other words to all inner stakeholders. Knowledge, skills, loyalty have become the determining factors in the success of an organisation. Higher share of value added goes back to knowledge. The connected topics of knowledge management are the intellectual capital, knowledge-economy, learning organisation, and organisational learning.

The output of higher education must meet with the need of the world of organisations. The question to be answered is, what does it mean: value creating in higher education? Value creating is over the education. Today building up the necessary skills in higher education, to teach students to be motivated is one of the most difficult tasks. True motivation comes from achievement of personal development, job satisfaction, and recognition, identity over the hygienic motivation factors should be considered as real motivating tools. The thought "I want to be the best" must be intrinsic. So how can higher education help the young generation to strengthen such skills as skills in debate, attitudes to problem, leadership, etc.?

A paradigm change has taken place in leadership: leaders must be problem-solving ones who recline upon the problem-solving individual.

\section{REFORM OF THE EUROPEAN HIGHER EDUCATION}

The reformed models can be dated back to the early $1800 \mathrm{~s}$. One is the French model, when the so-called Napoleonic university (with strong state influence) was established and broke with the former, religious, and denominational nature in 1808 . The so called grand écoles were 
specialised, where the main task of the teaching staff was education and it was not a strict requirement to take part in scientific research. After the reform, the universities were centralised and secularised, with a high level of hierarchy of the role of the state.

It the beginning, the role of the Prussian, or Humboldtian university (autonomic university) was also to educate high qualified functionaries for the state. Later more important became the science from XVIII. century in the life of the university. As the Prussian universities got importance after the Unification of Germany (in 1871), universities received great state support. Synthesis of education and science appeared. To help the students enter into the research world became an important task for the professors. The relationship between the student and the professor needed to be changed and it got closer to ancient Greek systems.

At the end of the $20^{\text {th }}$ century, a reform of the European higher education took part in the European Union. It is called the Bologne process. The Bologne process aimed to implement three-cycle training and set up the institutional framework for lifelong learning (with the improvement process of the competitiveness of the European economy (Lisbon Strategy). The increasing number of students in higher education and their large proportion within their age group during the last two decades have imposed new conditions to all the actors of higher education. Higher education must be suitable for numerous expectations, due the former mentioned changes of the expectations of organisations (business and public), and science. Without claiming completeness here, we mention beside problem focusing and the competence base education, the dichotomy of scientific training. Higher education should meet the requirements of practice oriented on business and scientific academic life at the beginning of the three stages system (Lőre \& Bencsik, 2008; Abrahão \& Lucchesi, 2009; Takács et al., 2009; Takács-György \& Takács, 2012). As more and more students enter into higher education, mass training is characteristic. In 2003 about $80 \%$ of the 20-24-year-old youth was involved in higher education in the USA, while this proportion was only $57 \%$ in the European Union and $50 \%$ in Japan (UNESCO and EUROSTAT; Delivering on the Modernization..., 2006). There was a strong intention to increase the number of students entering into higher education. At the same time, an important duty of the teaching staff remained to find the talented students, to help them and the conscious assistant to promote the evolving talent. 
Before the transition period, a low share of students who graduated from secondary school was allowed to enter into higher education in Hungary, after a strict, typical selection process. Only one quarter of the applicants could start their studies. The selection process contained a written and an oral part and also the scholastic records counted. Due to the high number of applicants and the selection process - assuming the normal dispersion of student capabilities, besides the presumable invariability of eminence frequency - it can be stated that a higher share of talented, clever students started their studies before the late 1980s. Before the Millennium, the number of students in higher education quintuplicated (Figure 2). That allowed increasing the possibility of also involving the less talented into higher education. As higher the number of the students is, the more interest goes on the output side: who will employ the graduated students, what kind of skills will they need, how important will be the "business - thinking" so more importance goes to "being a consumer the student is" expectations (George, 2007; Zhang, 2007; Takács et al. 2009).

The main market principles work in the domestic and international market of higher education. If there are "consumer needs", coming from economy, business, public sectors not only the different required skills, competencies - i.e. the outputs of higher educational institutes should be defined - but whom to educate, at which level, in which institute (in public financed or private colleges, universities), etc. For the consumer (entering students) the role of price/value ratio has become more important in choosing the adequate university or college, which requires a new approach from the institutions in regards to the pricing and calibrating of the level of training services. The internationalisation process of higher education (supported with student exchange projects like CEEPUS, Erasmus, or Erasmus ${ }^{+}$in Europe) raised competition among the universities. Despite the increase in the number and share of business and practicing education, it should be underlined that there will always be some "consumers" who prefer quality training, therefore the role of talent care remains important.

The appearance of students en masse, the radical increase of teacher tasks, duties have created a less favourable environment for talent management. To find good models, solutions for talent management is the task, which higher education faces. 
(1000 student)

(\%)

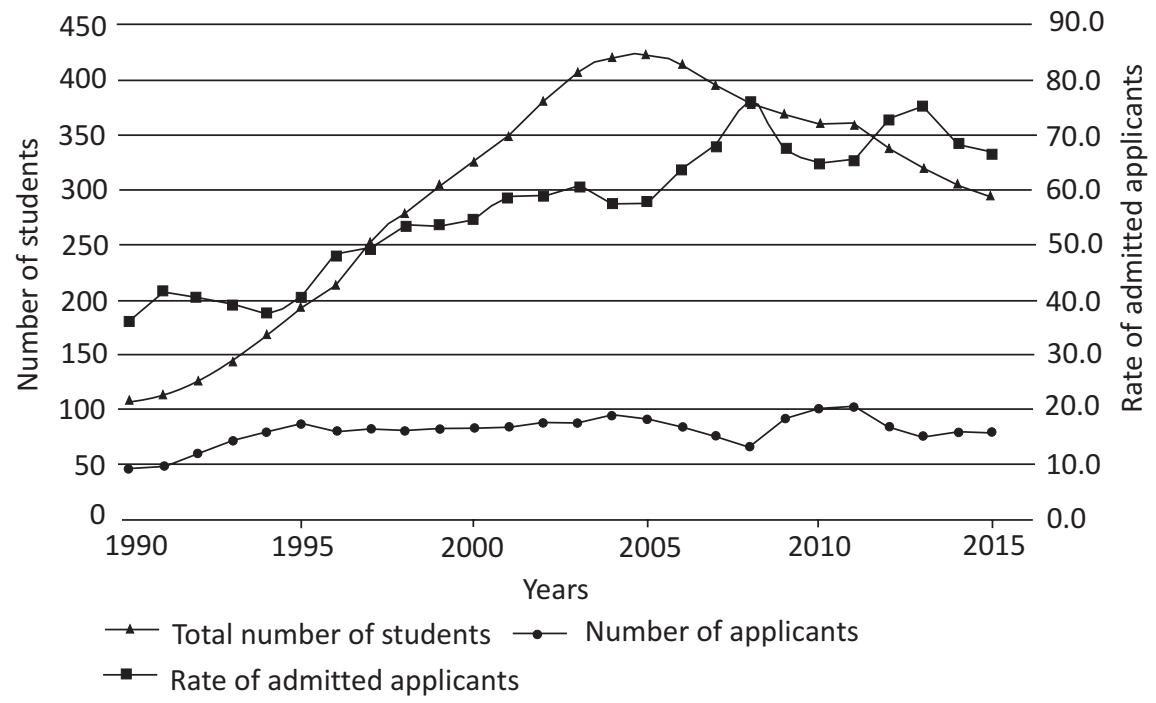

Figure 2. Rate of students in higher education, applicants and admitted applicants (1000 students; 1990-2015)

Source: based on data of the Hungarian Statistical Office, own construction.

\section{HOW TO HELP STUDENTS MEET THE REQUIREMENTS OF ORGANISATIONS? - A UNIQUE WAY FROM HUNGARY: THE MOVEMENT OF THE STUDENTS' RESEARCH SOCIETY}

\section{Talent management models}

Talent management is one of the tasks of higher education, but first we need to know what we understand as talent management. Talent (the word comes from Latin) means the person who is power of mind by the explanatory vocabularies. We think that the talent of the student has a wider meaning, today. Not only the IQ, but EQ is also important. Talent and creativity are the main sources of innovation, coming from human capital (see the question of invisible capital).

What is talent? Being unlike the others. It is very hard to discover the "difference" from the average, conventional, cultural, and social 
expectation. Something is considered as deviance, but behind the distinct behaviour, the non-attention, and backwardness at school there can exist a talent or creativity. Talent of painting, math, writing, a higher emotional and intelligence quotient, charisma, vision. What is important: to be talented, creativity is needed. Creativity is a capability of alteration, to do something in another way than we - or others - have done before (see innovation). Who has the right to declare: who is a talent? By professor Csermely everyone has the right to declare the talent, who has the sense of quality and impulse for novelty and is able to combine quality with novelty. The playful youth and the wise veteran compose the best team (Csermely, 2014).

Renzulli (1977) developed his 3-Ring Conception of Giftedness/ Talent. As the components of talent, he identified gift over average, loyalty to problem solving and creativity. More importance should go to the development of analytic thinking, language arts, and math skills in education. One of the greatest Hungarian doctors, the geneticist Czeizel (2004) identified - similar to several other talent-models - four factors: general abilities above average (good abstract mind, memory, effective information process, etc.); creativity (originality, flexibility, attitude to problems); commitment to tasks (enquiry, spirit of emulation, steadiness, emotion stability); special abilities over average (in: Konczosné Szombathelyi, 2012, p. 2).

A talented person needs knowledge, but if above knowledge the above mentioned soft factors exist, the issue can be combined with the development process of knowledge management (Figure 3). Wisdom requires a bit more than simple understanding of a problem and repeating former solutions. Based on understanding of the basic principles, combining, and creating new models, solutions - is not far from being creative, from innovation. Here knowledge management gains importance in talent management. It should be discovered for the students how to get closer to be wise (in other words: the best in something from both points of view: IQ and EQ).

Talent management is a term rooted in HRM literature. Collings and Mellahi (2009) withdraw in their definition the potential "Activities and processes that involve the systematic identification of key positions which differentially contribute to the organization's sustainable competitive advantage, the development of a talent pool of high potential and high performing incumbents to fill these roles, and the development of a differentiated human resource architecture 
to facilitate filling these positions with competent incumbents and to ensure their continued commitment to the organization" (Collings \& Mellahi, 2009, p. 304).

Knowledge Management

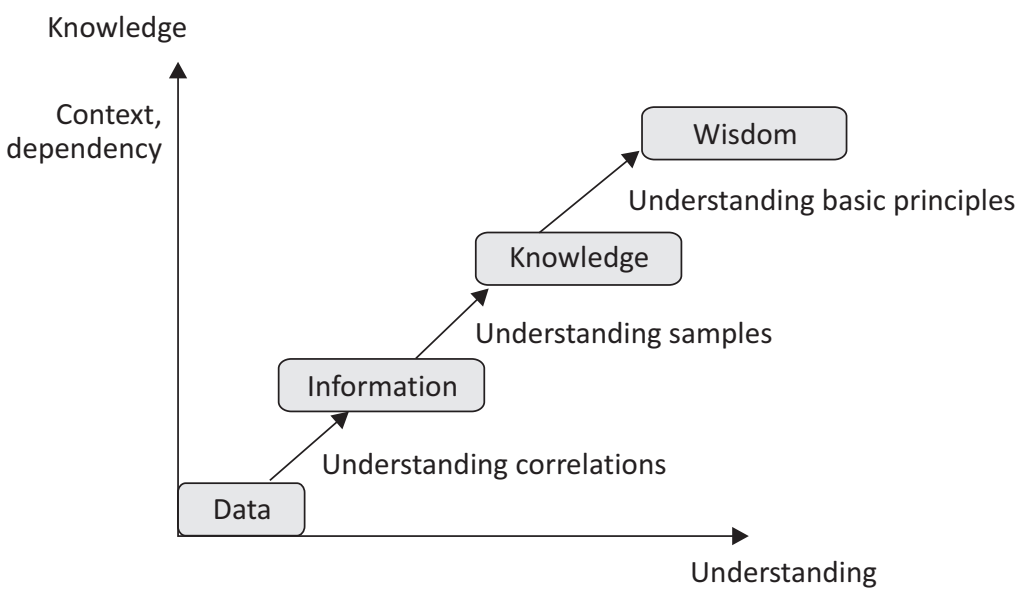

Figure 3. Process of knowledge management

Source: own construction.

The types of talent management can be classified based on the role of the teacher, the role of self-organised groups, associations or student competitions in higher education. Differences on this subject can also be made. Different is the real scientific talent management - involving the students into the scientific research work, groups, publications, etc. - or the "business" talent management, with creating and managing business organisations, solving case studies, etc. One special area of talent management are the student mobility programs (Erasmus, Erasmus ${ }^{+}$, CEEPUS, etc.), where the student has to organise their studies, accommodation, additional financial support, in other words they enter into life. More and more solutions, conventional and internet-based students' championships, case study competitions are organised out of higher education, by business organisations. All of them broaden the frame of education, give floor for the students to try themselves in a non-educational environment, they have to work in teams, to make decisions, with their responsibility, to manage and organise the task. What else is then a trial for abilities? What they 
need is knowledge, abilities, and skills. Due to the limitation of the paper we did not go deeply into these talent management models/tools of higher education, existing in Hungary as well.

There are also models of talent management based on the subjects taught at higher education at faculties. Good, inquiring students can be invited into education (as demonstrators) and/or research and later into the students' research societies work. The challenge is how to find the most opened students at their first academic year? That is one of the most difficult tasks of teacher staff after the implementation of the Bologne system (Czakó, 2006). Weiszburg (2008) also highlighted the problem of the shortened training period on the Bachelor level. To find the 10-15\% of talented students and to select from them the $1-3 \%$, to start them at the scientific career is harder than it was in the former system.

The traditional universities are involved not only in the scientific side of the training (i.e. Master and $\mathrm{PhD}$ level), where the role of scientific research is determinant, they also have to find the tools, models for meeting the requirement of business. Talent in business means more practical issues, like project solving orientation. In those universities, colleges where the Bachelor level is general, the more practical, problem oriented competitions, case studies are the talent management tools (Takács \& Takácsné, 2010).

The system of talent management is built on elements within and out of the institutions, talent management (care) within the institution involves teaching staff, who feel bound to participate in it, and institutionalised events. Special colleges, student conferences, taking part in case studies, championships as well as other incentives (scholarships, awards for excellent progress, recognition of scientific achievements as extra study progress, etc.) can be the scenes of work with the students, so that not only their knowledge can be developed, but also arguing or organising abilities. There are projects out of the institutions, which include state scholarships for excellent study progress, scholarships from foundations, conferences organised by public institutions and private organisations, study competitions, case study competitions, etc. 


\section{Students' research societies - special task in higher education}

\section{History of students' research societies}

The students' research societies, the movement of special Hungarian talent management is unique in the world.

The beginning dates back to the 1951-52 academic year, when a new type of teacher - student work appeared spontaneously at some Hungarian universities. The announcement invited applications on an optional (not compulsory topic in the studies) and after a strict selection the best "papers" were to be presented. Special, auto-training student groups of 20-40 members, with the support of professors were formed. Here, invited experts gave lectures on special, scientific topics, there were discussions organised as well, and the curious, open-minded students could find interesting topics to examine as scientific research. Also important was to introduce the youth into the way of scientific publications. The number of students taking part in higher education grew up radically until 1953. About 45 thousand students studied at 71 university faculties and 97 local students' research societies were registered up to the end of 1952. Two thirds were engaged in life sciences and technology. These organisations fought for their autonomy at that time, and many professors, teachers stood with the students' research societies, which became a "free place for disputes".

The first National Students' Research Conference was organised in April, 1955. 109 studies were presented at 19 specialised conferences, in the name of more than 2,000 students, from 300 student research societies. The movement was considered not only as the autonomy of universities, independent work and consultation between the student and the tutor, but was a part of the scientific independence from the actual policy and autocracy. The secret of the success of students' research societies was "the good research topic; suggestive erudite individuality" that emerged good examples (Anderle, 2001, 2006). After the Revolution in 1956 the movement went through changes, but was able to remain as a quasi-autonomous part of higher education. There was a central regulation: to become a member of a students' scientific society an application to the formerly existing Communist Youth Association (KISZ in Hungarian) was required. The coming National 
Students' Research Conference was organised in five sections: social, life, technical, agricultural, and medical sciences (1959), with 295 presentations. 429 presentations from 500 students were presented at the $4^{\text {th }}$ conference in 1961 . More and more students, tutors were involved in the scientific research, the scope of topics became wider, and more presentations dealt with social sciences.

In the second half of the 1960s the selection process changed and the role of pre-evaluation of a written thesis increased. The length of the thesis was not declared (minimum - maximum), but the structure and the content was supposed to follow the scientific requirements. The National Conferences remained the territory of the universities and some leading colleges basically, though there were some thoughts to make it international, the system - and the language of the conferences - remained Hungarian. About $10 \%$ of the students of Hungarian higher education were members of the scientific research societies $(4,000-5,000)$ at that time. Awards for tutors were introduced in 1970. The role of the tutors was also highlighted. László Lovász, an academic (today the president of the Hungarian Academy of Sciences) took part in the conference with more thesis of which one was considered as the level of candidate degree of the Hungarian Academy of Sciences (Anderle, 2006). That was the point in the history of National Students' Research Societies, when it was said that this movement was a competition not only between the students, but between their tutors and home universities, their faculties.

The National Council of Students' Research Societies (OTDT in Hungarian) was established and regulated the operation in 1972. The organisation of the $10^{\text {th }}$ Conference (1972) received high attention not only from the politicians, but from the media and got a "festival feeling". Eight universities organised the conference and a novelty was that a section of Marxism - Leninism and Economy was organised. 928 theses were presented in 45 sub-sections of the 8 sections by 1,974 students and 532 teachers. The increase in the number of participating persons showed not only their interest in scientific research work, but the movement remained a little the scene of unbound thinking.

The unchanged interest in students' scientific conferences caused some problems in the organisation of the $12^{\text {th }}$ Conference. 1800 theses were presented in 120 sub-sections of the enhanced 12 sections (information science, pedagogy, chemistry). The evaluation system was standardised, the programs were announced before the conference, the abstracts (resume) of each section, were printed. Entering into the 
fourth decade of the history of students' scientific research movement, the universities of sciences, agriculture, and medicine were the most involved in the students' work and in organising the conferences. With the growing number of the presented theses less time remained for the discussion of the results, so instead of a discussion panel, competition between the faculties, universities became stronger. The characteristic of research groups got eclipsed, more individual student work appeared, but the tutorial connection between the student and the teachers remained. Beside the demand of establishing special committees of the sections, financial support was needed. The other change was in the extension of the potential student's base of entering students into scientific research societies, named the so-called Colleges for Advanced Studies. These types of student organisations were formed to extend the floor of scientific works, discussions, argues and to widen the knowledge of students, of course. Students admitted into colleges for advanced studies - after a strict selection based on their study results, public activity, affinity, agility were moved to special dormitories and tutored by academic staff, but the organisation was self-governed. The auto-training character was dominant.

By the beginning of the 1980s more optional ways appeared in higher education, such as optional subjects besides the compulsory ones, education became more flexible, also a choice of courses was given, however, the role of scientific research associations remained important. At the peak of the 1980s there were 1,895 when 2,151 theses were presented. Due to the limited number of the allowed, entering students over $5-35 \%$ of the active students were involved in the students' scientific research movement, depending on the different faculties and disciplines. The number of the students in higher education was 62-64 thousand per year. The National Council of Students' Research Societies was re-organised in 1985, more representatives of the Sections became the members with the increasing rate of students and an operational board was founded. The new aim of the movement - talent management - was introduced in 1987 by the newly elected president of the council, Péter Szendrô. The evaluation processes of the sections were converged to each other, the journal of the Students' Research Societies, named Student Clark (Diáktudós) was established, the council became the forum of lobbying for students. The Pro Scientia gold medal award was established in 1988. The winners at the national conference can apply for the Pro Scientia gold medal, out of which not 
more than 50 are awarded by the Council of the Students' Research Societies biannually. The base of the adjudication is the successful, outstanding student research work, language knowledge, publications, conference participations, study results, and public activities. The sections give ranks, but the final decision goes to a special committee. The tutors of the students honoured with the Pro Scientia Gold Medal receive a special medal. To honour the tutors' work, active participation in the students" scientific research societies, the honorary title of Master Teacher is given to 50 outstanding persons, biannually. The independency of the movement from the politics got more intensive by the socio-economic transition, that reflected in the changed topics of the theses, mainly in the Section of Economy and Human Sciences (Anderle, 2001, 2006).

In the first half of the 1990s, the gate to higher education was opened to more students as the universities, colleges were interested to increase the entering number of the students, corresponding, long distance educational forms appeared besides the former "normal" courses. The less time the teaching staff had, the more students were in, so the individual, personal contact got into the background instead of talent management. The harder task was to find the talented, questioning, loyal to science students. This was not reflected in the number of the presented theses at the national conference (in every second year; 1,812 theses in 1993 and 2,293 in 1995). The new agent was the appearance of ecclesiastical and private, smaller higher institutions, universities, colleges and their participation at the national conferences. Through the integration process of the governmental financed institutions, their number decreased radically (by one-third).

The Council of the Students' Research Societies became a self-organised, professional, coordinative organisation. The question of finance of the organization was sold by the new law of higher education in 1995. It was delegated $0.001 \%$ of the norm of higher education to finance the operation of the Council. That makes the whole movement more calculable. There was a radical increase in the number of those nominated to national conferences at that time (from 2,568 theses in 1997 to 3,089 theses in 2003) (Anderle, 2006).

After the millennium, the higher education suffered from continuous changes (introduction of the Bologne system, integration of institutes, radical decrease of governmental financial sources, high pressure to become a business type organisation, to run after research projects, 
etc.), while the number of incoming students has decreased since the peak years 2004-2006. Both the economic and political environment was erratic, the individual ministry of education was liquidated and merged into the Ministry of Human Resource (i.e. less money, less regards went to higher education since 2010). Despite the negative changes, the Hungarian students' scientific research societies have remained to be a strong, national movement during the last decade. The partnership between student and teacher, the cooperation of the student with the tutor appears as the symbols of commitment, the sense of vocation, based on competences and far from the actual politics. This has risen the students' scientific societies, the movement over everyday disputes, attacks, and the permanent changes in higher education and the movement can remain one important - especially from the point of view of the future of science - tool of talent management (Anderle, 2011).

\section{Present situation of students' research societies}

Paragraph 66 of the Hungarian Higher Education Act (CXXXIX of 2005) deals with talent management, specifying - among others $\mathrm{PhD}$ training and special colleges for advanced studies - students' research societies, as a means of quality education and development of talents.

The National Council of Students' Research Societies is named in $\S 79$ (6) of the Act thus ensuring the state recognition of the Council's work. The organisation is a public body consisting of delegates from universities and colleges. Its objective is to support the institutional management of students' extracurricular scientific activities and to present biennially the scientific and artistic papers and works made in already 16 sections by today, in different fields of sciences and arts. The sections are as follows:

- Agricultural Sciences;

- Law and Political Sciences;

- Biology;

- Physics, Earth Sciences, and Mathematics;

- Military Sciences;

- Humanities;

- Information Technology Sciences;

- Chemistry and Chemical Industry;

- Economics;

- Engineering; 
- Fine Arts and Arts Sciences;

- Medical Sciences;

- Pedagogical, Psychological, Cultural Education, and Library Science;

- Subject Pedagogy and Education Technology;

- Social Sciences;

- Physical Education and Sports Sciences (Figure 4).

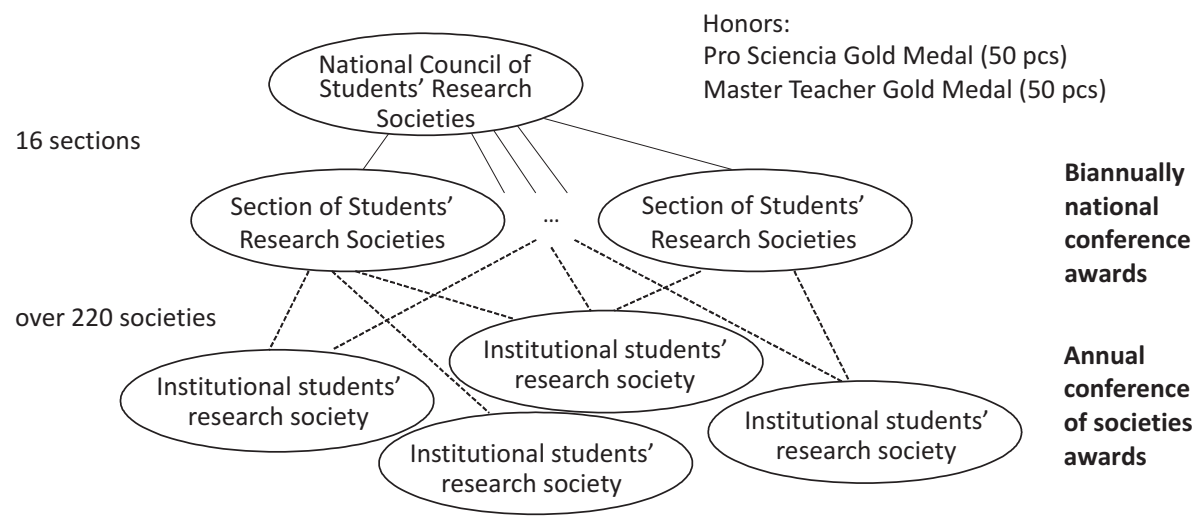

Figure 4. The organisational structure of the Students' Research Conferences

Source: own construction.

The Students' Research Societies exist at nearly each faculty of the Hungarian higher educational institutes. They organise conferences every year - or in every semester in those faculties where the number of students is high enough - the students have to write a thesis (the length depends on the discipline and the rules of the Section). There is an evaluation process of the thesis (generally by two opponents). The thesis should be presented and defended at the local conferences, where the presentation is evaluated by a local committee, too. The national conferences are organised by the section, further divided into subsections - today in 16 sections - according to the scientific and artistic fields (see above). The presentations in the subsections are evaluated by juries who award prizes considering both the submitted essay and presentation held at the conference. A maximum of one-third of the presentations can receive prizes.

It is the responsibility of the local conference committee and the local council of students' scientific society to nominate the best students 
to the biannually organised national conferences. It is the practice to nominate less than one quarter or one fifth of the presented theses at local conferences to the national conference.

The competition essays submitted to the institutional conferences are forwarded to the national conference. The juries at the institutional conferences award prizes for the essays and suggest to enter them in the national conference. Again, not more than one-third of the presentations held at the institutional conferences can be rewarded.

The number of the nominated students had grown radically till 2013-2015 (Table 1). Among the students taking part in the national conferences there is no significant difference between males and females, but in the last three national conferences a slow increase in the share of female students was observed. There is a negative change at the level of awarded Pro Scientia students, where only $40 \%$ are female (Baranyiné Réti \& Koósné Török, 2006; Koósné Török \& Baranyiné Réti, 2008). Among the tutors of the awarded students, the share of females is only $29 \%$. The difference between gender here appears at first in their scientific life, in the academic carrier. The number of female academics at the Hungarian Academy of Sciences is less than $5 \%$ ! To discover the reasons is not the aim of the paper, but the issue should be examined in the future.

Table 1. Some figures of former Students' Research Conferences (2009-2015)

\begin{tabular}{|c|c|c|c|c|c|c|c|c|c|c|}
\hline Category & \multicolumn{2}{|c|}{$\begin{array}{l}29 \text { th } \\
(2009)\end{array}$} & \multicolumn{2}{|c|}{$\begin{array}{c}\text { 30th } \\
(2011)\end{array}$} & \multicolumn{2}{|c|}{$\begin{array}{c}\text { 31st } \\
(2013) \\
\end{array}$} & \multicolumn{2}{|c|}{$\begin{array}{l}\text { 32nd } \\
(2015)\end{array}$} & \multicolumn{2}{|c|}{$\begin{array}{c}\text { 33rd } \\
(2017)\end{array}$} \\
\hline 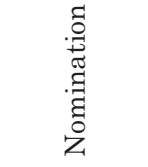 & 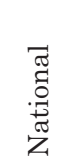 & 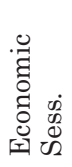 & 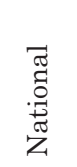 & 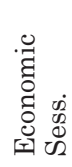 & 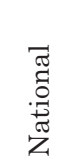 & 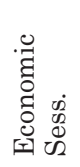 & 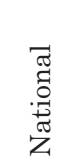 & 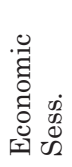 & 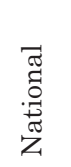 & 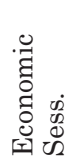 \\
\hline Subsection & n. a. & 35 & 422 & 56 & 494 & 57 & 548 & 43 & 501 & 39 \\
\hline $\begin{array}{l}\text { Presented } \\
\text { thesis }\end{array}$ & 4603 & 431 & 4169 & 494 & 4611 & 570 & 4603 & 442 & 4111 & 350 \\
\hline
\end{tabular}

Source: own calculation, based on OTDT statistics.

That increase did not follow the changes in the number of students in higher education, the peak is approximately $3-5$ years later. It can be stated that about 22-25 thousand students are involved in every two years from the total number of students taking part in higher education (see Figure 1). If we compare the number of the students 
involved in students' scientific research societies, nowadays only $6-10 \%$ of the students get the opportunity to be a member of this talent management movement. (Although this rate is much lower than it was in the 1980s, it must be taken into consideration that about half of the students are in atypical courses, so mainly they are adults, have their job, family, so it is harder to find the time for research activities) (Cziráki \& Szendrő, 2016).

It cannot be stated that students' scientific research societies are only talent management tools for the state universities and colleges. Good infrastructural bases, motivated teachers work in more practice oriented private higher institutions, they also take part in research, and students' scientific research societies have been formed, too. There is a significant difference between the universities and the colleges concerning the proportion of those with scientific degrees. At the public universities, the rate of full time teachers with scientific degree was $44.5 \%$, in public colleges $22.3 \%$, while in private universities it was $41.6 \%$, and $29.8 \%$ in private colleges (Takács \& Takácsné, 2010). The scientific background is not different according to the founder and type of institution. However, if we examine the rate of the awarded papers projected on the capacity in the groups of institutions we find that the essays made at the traditional universities have twice as much chance at the conferences than the essays submitted from younger - but still having great traditions - institutions, and four times as much than the institutions founded after the socio-economic transition. The analysis according to the type of institution, however, proves that it is a distorted result because the low performance of colleges destroys the value of indices (Table 2).

The institutional conferences are typically held annually, while the national conferences are organised biennially. The location of the national conference is different year by year. The higher education institutions apply for the organisation and receiving the right of organisation also means the recognition of the institution's activities in students' research.

Today there are about 450-500 winner students by each national conference. Considering the number of the first, second, and third places and special prizes won by the institutions, the differences in eminence of the students are assessed in proportion to Pro Scientia medals, knowing the mechanism and practice of awarding. The National Council of Students' Research Societies confers the honorary title of 


\begin{tabular}{|c|c|c|c|c|c|c|c|c|c|c|c|}
\hline 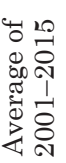 & & $\begin{array}{l}\text { 동 } \\
\text { N } \\
\text { o }\end{array}$ & $\begin{array}{l}\infty \\
\stackrel{2}{ } \\
\text { ô } \\
\stackrel{-}{-1}\end{array}$ & $\begin{array}{l}\vec{\infty} \\
\stackrel{0}{\infty} \\
\dot{0} \\
\dot{0}\end{array}$ & & $\begin{array}{l}\mathscr{D} \\
\text { Nै } \\
\text { oे } \\
\text { ง่ }\end{array}$ & $\begin{array}{l}\stackrel{ }{\mathrm{N}} \\
\stackrel{\mathrm{H}}{\mathrm{H}}\end{array}$ & $\begin{array}{l}0 \\
\text { N } \\
\text { م } \\
\text { - }\end{array}$ & $\begin{array}{l}\text { Na } \\
\text { No } \\
0 \\
0\end{array}$ & $\begin{array}{l}\hat{0} \\
\stackrel{0}{0} \\
0\end{array}$ & $\begin{array}{l}\infty \\
10 \\
=\end{array}$ \\
\hline$\stackrel{10}{\stackrel{10}{0}}$ & & 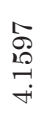 & 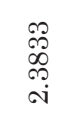 & $\begin{array}{l}\text { Do } \\
\text { ำ } \\
\text { r }\end{array}$ & & \begin{tabular}{l} 
O \\
\multirow{4}{0}{} \\
is
\end{tabular} & $\begin{array}{l}8 \\
8 \\
8 \\
10\end{array}$ & $\begin{array}{l}\text { N } \\
\stackrel{N}{\delta} \\
\stackrel{0}{0}\end{array}$ & $\begin{array}{l}1 \\
\infty \\
0 \\
0 \\
0 \\
0\end{array}$ & \begin{tabular}{l}
$\mathscr{0}$ \\
$\stackrel{0}{0}$ \\
\multirow{H}{*}{}
\end{tabular} & $\underset{\sim}{\stackrel{\mathscr{্}}{+}}$ \\
\hline$\stackrel{m}{\stackrel{\infty}{\circ}}$ & & 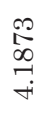 & 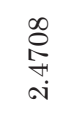 & $\begin{array}{l}10 \\
\stackrel{10}{\infty} \\
\stackrel{-}{-}\end{array}$ & & $\begin{array}{l}\mathscr{0} \\
\stackrel{0}{0} \\
\infty \\
\infty\end{array}$ & $\begin{array}{l}\infty \\
0 \\
0 \\
\infty \\
\infty\end{array}$ & $\begin{array}{l}\text { 등 } \\
\text { 엉 }\end{array}$ & 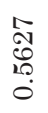 & $\begin{array}{c}\mathcal{N} \\
\stackrel{\sigma}{f}\end{array}$ & $\stackrel{\substack{\infty \\
\varpi}}{+}$ \\
\hline 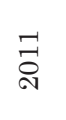 & & 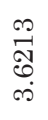 & $\begin{array}{l}\text { Nै } \\
\text { Oे } \\
\text { i }\end{array}$ & $\begin{array}{l}\stackrel{0}{0} \\
\stackrel{9}{-} \\
\stackrel{-1}{-1}\end{array}$ & & $\begin{array}{l}\infty \\
\text { D. } \\
\stackrel{2}{-} \\
\stackrel{\sim}{\infty}\end{array}$ & $\begin{array}{l}+ \\
8 \\
\infty \\
\infty \\
\infty\end{array}$ & $\begin{array}{l}\infty \\
\infty \\
20 \\
0 \\
-\end{array}$ & $\begin{array}{l}1 \\
\infty \\
0 \\
0 \\
0 \\
0\end{array}$ & $\begin{array}{l}\stackrel{8}{0} \\
\stackrel{7}{7}\end{array}$ & $\begin{array}{l}0 \\
\text { Nै } \\
\text { م. }\end{array}$ \\
\hline \&ి & & 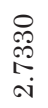 & $\begin{array}{l}\mathscr{B} \\
\stackrel{1}{+} \\
\stackrel{+}{-}\end{array}$ & $\begin{array}{l}\mathscr{0} \\
\stackrel{5}{10} \\
0 \\
0\end{array}$ & & $\begin{array}{l}\text { ন } \\
\text { ন } \\
\text { ง }\end{array}$ & $\begin{array}{l}0 \\
\text { on } \\
\text { in } \\
\text { id }\end{array}$ & $\begin{array}{l}\text { N } \\
0 \\
0 \\
0 \\
0\end{array}$ & $\begin{array}{l}? \\
2 \\
0 \\
0 \\
0\end{array}$ & $\underset{\text { 年 }}{\text { 品 }}$ & s. \\
\hline 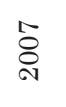 & & $\begin{array}{l}\infty \\
\infty \\
\infty \\
\infty \\
\text { ì }\end{array}$ & 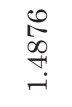 & $\begin{array}{l}\stackrel{+}{\sigma} \\
\stackrel{D}{\Sigma} \\
\dot{0}\end{array}$ & & $\begin{array}{l}\mathscr{0} \\
0 \\
\infty \\
10 \\
\text { iv }\end{array}$ & $\begin{array}{l}+ \\
0 \\
0 \\
0 \\
0\end{array}$ & $\begin{array}{l}10 \\
\underset{+}{+} \\
\stackrel{1}{+}\end{array}$ & $\begin{array}{l}\text { ㅇ } \\
\text { 今 } \\
\text { ஸุ } \\
0\end{array}$ & $\begin{array}{l}\text { Pా } \\
\infty \\
\text { ర) }\end{array}$ & $\begin{array}{l}\infty \\
\infty \\
\infty\end{array}$ \\
\hline 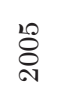 & & 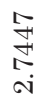 & 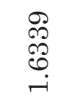 & $\begin{array}{l}\vec{N} \\
\mathbb{N} \\
0\end{array}$ & & 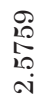 & $\begin{array}{l}0 \\
10 \\
10 \\
\infty \\
0 \\
0\end{array}$ & 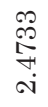 & $\begin{array}{l}\underset{+1}{10} \\
\stackrel{9}{0} \\
0\end{array}$ & $\underset{\stackrel{\mathscr{P}}{+}}{\stackrel{\rho}{+}}$ & $\stackrel{8}{8}$ \\
\hline జ & & $\begin{array}{l}\underset{\sim}{\infty} \\
\underset{\sim}{\mathbb{N}} \\
\text { id }\end{array}$ & $\begin{array}{l}0 \\
0 \\
0 \\
0 \\
- \\
-1\end{array}$ & $\begin{array}{l}\text { So } \\
\stackrel{+}{+} \\
\dot{0}\end{array}$ & & 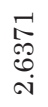 & $\begin{array}{l}\overrightarrow{0} \\
\stackrel{-}{0} \\
\dot{0}\end{array}$ & $\begin{array}{l}\vec{\sigma} \\
\stackrel{+}{+} \\
\stackrel{+}{+}\end{array}$ & 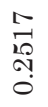 & $\begin{array}{l}\text { D } \\
\infty \\
\text { O) }\end{array}$ & $\underset{-1}{\stackrel{0}{0}}$ \\
\hline 옹 & & $\begin{array}{l}\underset{+}{\infty} \\
\underset{\sim}{ \pm} \\
\text { ㄱ }\end{array}$ & $\begin{array}{l}10 \\
\infty \\
\infty \\
\infty \\
\\
-\end{array}$ & $\begin{array}{l}10 \\
5 \\
\infty \\
0 \\
0\end{array}$ & & 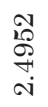 & $\begin{array}{l}+ \\
\infty \\
\infty \\
+ \\
+ \\
0\end{array}$ & $\begin{array}{l}\infty \\
i 0 \\
\infty \\
\infty \\
\text { o } \\
\text { on }\end{array}$ & $\begin{array}{l}\text { ⿵ै } \\
\stackrel{-}{-} \\
\stackrel{-}{0}\end{array}$ & $\begin{array}{l}\text { Do } \\
\infty \\
\text { o }\end{array}$ & $\begin{array}{l}\text { 용 } \\
\text { \& }\end{array}$ \\
\hline 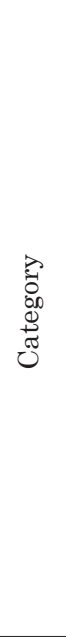 & 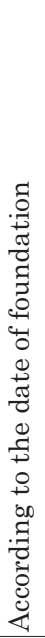 & 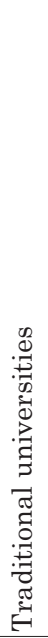 & 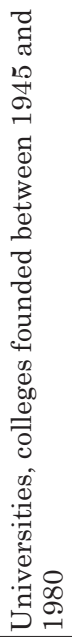 & 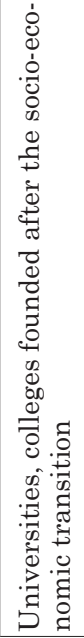 & 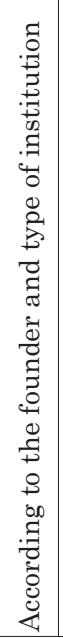 & 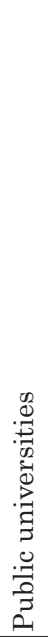 & $\begin{array}{l}0 \\
0 \\
0 \\
0 \\
0 \\
0 \\
0 \\
0 \\
0 \\
0 \\
0\end{array}$ & 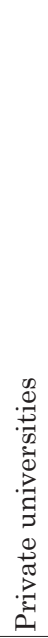 & 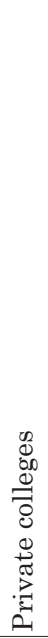 & 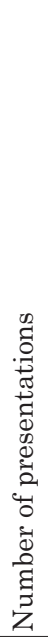 & 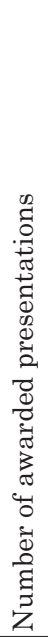 \\
\hline
\end{tabular}


Master Teacher in recognition of the tutoring for students and the achievements in talent care. Biennially maximum 50 teachers can receive the title for outstanding tutorial work. All the winners of the national conferences, the name of the awarded students and tutors are public and announced on the official website of the National Council of Students' Research Societies (www.otdk.hu). For the students, the ranking, the special awards are entrances to start their $\mathrm{PhD}$ studies, for the tutors to get the Master Teacher title is one of the highest regard is the process to become a full-time professor, as the result of successful talent management.

\section{Why students' research societies, the movement is really a talent management tool?}

Students' Research Societies are existing nearly at all faculties in higher education in Hungary. All the students can join a society, can start their scientific research, with a tutor. From this aspect, it can be stated that the movement is acceptable for everyone, who wants to work harder over his/her compulsory studies. As it was shown with the figures, $6-10 \%$ of the students take part in the local conferences, but the number of students who finish and present the thesis is less than the number of total involved students. Not only the most talented students get the possibility to join the movement - i.e. 1-3\% as Weiszburg (2008) stated, to find is one task - so greater number of students will become acquainted with the rules of scientific research and of course the feeling that "I have solved a problem".

During the scientific research the research question should be defined, the hypothesis stated, the necessary database and the appropriate methods found, and after the research the results should be put into a wider context. Based on strict literature analyses, the discussion of the results, the conclusions, suggestions should be drawn. These tasks help the students to strengthen their skills in problem solving, individual and team work and cogency. Also, the question of presentation, self-sale in talent management is important. As the students have to present their thesis - to highlight the main points, outcomes - and to defend the results, the students' scientific research activity is a good field to get the practice (to get accustomed to situations different from "normal school classes). In the research groups, they work together several times on a research project, they have to cooperate. 
More students can be reached and motivated to carry out student researches than in taking part either in conventional or Internet-based students' championships, case study competitions, due to the fact that they can choose their research questions based on their special interests, so higher is their motivation (self-realisation). It is better if the students' scientific research activity is a real component of the organisational culture of the universities, where the successful students and their tutors are honoured. We mean not only the financial honour, as a message to both sides, rather the moral honour is important. The students' scientific societies should give good examples, benchmarks for the incoming younger student, showing that everyone can take part in research work (teams), reach good results, can stand up before a scientific committee and of course the schoolmates, can defend their own results, so nothing is beyond possibility. Both the successful students and tutors are benchmarks for the new generations.

Participation in the mentor system, to be a tutor of the students gives acknowledgement, carrier possibilities for the teachers and it is a component of criteria to meet the requirements of becoming a full-time professor.

The number of entering students into higher education is decreasing in Hungary, too, as it was discussed previously. The better students want to be admitted into the big universities, mainly in Budapest. There is a huge competition between the universities for the best (good) students. With the higher qualified students (generally having one or two state language exams) these bigger and more famous universities get "better inputs". But if we have a look on the non-official championships of the different faculties by disciplines, it can be found that both the number of the nominated students to national conferences and their successfulness, the gap between the taken over top and smaller rural faculties is narrowed.

Let see the example of the Economic Section of the 33rd National Students' Scientific Conference. 350 theses in 39 subsections were presented. 116 prizes were awarded (39 first, 43 second, and 34 third prizes). 25 faculties got some prize among the 29 nominating faculties. The 39 first prizes went to 14 faculties, the 43 second prizes to 16 faculties and the 34 third prizes were shared among 16 faculties. The non-official championship between the faculties of the discipline of economy, calculated by the Olympic method, showed an interesting result: the first two places went to two rural 
faculties, where the absolute number of the students is lower than the main, leading university of economics in Budapest (even if the results of the two faculties are summarised). The movement acts a part of a compensatory role both between the incoming students' qualification differences and the reputation of the different nominating faculties. (It should be added here that the results at national students' scientific conferences are including as a measurement into several ranking systems of faculties).

The biannually organised national conferences, in 16 sections give the floor to meet the superior and most attractive, representative teachers coming from nearly all faculties, research institutes of the discipline. For the students, not only meeting the members of evaluating committees and accompanying teachers is a great opportunity, but to meet students from other faculties, other regions of the country, to build up new acquaintances, friendships. Nowadays, the social network starts in the years of the studies, the increasing role of network in business life, in innovation, etc. is beyond dispute.

The organisers of local and national conferences, the motivated tutors all believe - like Professor Szendrô Péter, the President and Cziráki Szabina, the Secretary of the Students' Scientific Research Committee - that the movement is a momentous 'Hungaricum' from both the point of view of higher education and the Hungarian science. Its impact on the whole society can be observed, more than half of the participants enter into the third level of the Bologne system, after defending their PhD they can continue their scientific research at the academic sphere or get good jobs in business.

\section{CONCLUSIONS}

There are different types of talent management models, tools existing in the Hungarian higher education. One of the main tasks of higher education according to the introduced Bologne system (Bachelor Master - $\mathrm{PhD}$ ) must be devoting more interest to selecting the talented student and help him/her in their carrier, whether it is a scientific or a business one. The need for graduated students is high, but the need of skills has undergone radical changes in the last decades. More critical resource of organisations has become a human resource, i.e. human capital, "people are the main source". 
More valuable are those, who are open minded, responsible for new ideas, creating new value, have good ideas and are capable to work together, to cooperate by the organisational goals. The so-called soft factors have got higher importance in management, problem-solving, a self-confident human resource is needed who is able to work independently. If someone takes part in the students' research societies he/she can try not only his/her knowledge, but also other skills. The new generation is more purposive, they have their goals, want to be the best, want to get the best position, they are more open to study and work abroad than their parents had been, etc. (Foreign universities can acquire knowledge which is not offered at the home institution). They have the language knowledge, flexibility, open-mindedness, curiosity, etc. There are also such factors that changes the environment of higher education from the market side. The higher education institutions should face the fact that the students are to be treated like consumers. From this comes a threat for higher education. However, it should be added here, that international student mobility (based on credit equivalence) is also one of the possible means of talent management.

Summarising the roles of scientific student societies, they are the following:

- $\quad$ scientific research is problem focusing, competence based, face to face work with the tutor teacher - scientific training;

- scientific thesis - individual, problem solving research work, follows strict scientific structural and content requirements;

- $\quad$ should be presented before a scientific committee - helps to build up the skills of presenting and arguing;

- students should be responsible for new ideas, creating new value - that is critical of human resource (from the point of view of both business and public organisations);

- requirements of practice oriented business life and scientific academic life is the same - the adjusted knowledge transfer is needed.

New, competence based educational methods, team-oriented, problem solving project work instead of learn-the-data education are needed and the unique Hungarian Students' Research Societies movement meets these requirements of talent management. To be successful, at the very beginning of students' studies the teacher - student relationship (trust!) must be developed. 
To what can be comparable the student - tutor cooperation, work in scientific society? To the ancient Greek philosophers, to Aristotle and his school-masters' mates. When walking on the hill surrounded by disciples, they discussed together scientific, philosophical, political questions or arts, they were equal on the same floor, questions were answered and the disciples were introduced into the world of life.

We think that education must not be separated from research. All research topics are unique, thought they can be parts of bigger researches. The students' research can be considered as experimental fields, labs where all participants win, gain experiments and can improve themselves. At the Prussian type of universities, it worked well. Today, the results coming from the research activities are built in the education and talented students can take part in researches in the frame of the Students' Research Societies in Hungary.

The scientific potential at the universities provides a strong basis for talent management. The students' scientific research movement is one element of building up the necessary skills required by organisations through the chain of value creating - talent - valuable human resource (invisible capital of organisations). Helping the students to feel intrinsically "I want to be the best" and "I am the best", to believe that they are able to solve the problems, they are able to reach the goals is our task for the present and for the future in higher education.

The issue of talent management is one the most important points in higher education which is offered to the masses now all over the world.

\section{REFERENCES}

Abrahão, M. \& Lucchesi, S. (2009). Higher education policies for the XXI century: The future of emerging countries. Problems of Education in the 21st Century, 15, 90-98.

Anderle, Á. (ed.) (2001). A Magyar tudományos diákköri konferenciák fél évszázada (1951-2001). Budapest: OTDT.

Anderle, Á. (2006). A tehetségrôl-Beszélgetések a TDK-ról. Kiadvány: OTDT. p224. http://otdt.hu/upload/files/1.\%20a_tehetsegrol_beszelgetesek\%20a\%20TDKrol_2006.pdf (access: 25.06.2017).

Anderle, Á. (ed.) (2011). A magyar tudományos diákköri konferenciák története (1951-2011). Diáktudós. OTDT. Budapest, 2011. XXII. évfolyam, 1-4. összevont különszám. 
Argyris, C. (1966). Integrating the Individual and the Organization, 3rd ed. New York: John Wiley \& Sons.

Bakacsi, Gy. (2015a). A szervezeti magatartás alapjai. Budapest: Semmelweis Kiadó. Bakacsi, Gy. (2015b). Organizational culture. In: Su Mi Dahlgard-Park (ed.), The Sage Encyclopedia of Quality and the Service Economy. Vol. 1. Thousand Oaks (California): Sage Publications, 462-467.

Baranyainé Réti G. \& Koósné Török E. (2006). A fiatal tudós nók az Országos Tudományos Diákköri Konferenciákon és a Pro Scientia Aranyérmesek körében. Magyar Tudomány, 5, 616-622.

Barnard, C.I. (1938). The Functions of the Executive. Cambridge, MA: Harvard University Press.

Bell, D. (1973). The coming of post-industrial society. New York: Basic Books. In: B. Jessop, A Cultural Political Economy of Competitiveness and Its Implications for Higher Education, 13-39. Education and the Knowledge-Based Economy in Europe. Educational Futures Rethinking Theory and Practice. Vol. 24. 77 p. Sense Publishers. Rotterdam - Taipei. https://www.sensepublishers.com/media/303-education-and-the-knowledge-based-economy-in-europe.pdf .

Collings D.G. \& Mellahi, K.M. (2009). Strategic talent management: A review and research agenda. Human Resource Management Review, 19(4), 304-313.

Csermely P. (2014). Elôadás a tehetségrôl. OHE Konferencia - 2014. május 29. Csermely Péter előadása. https://www.youtube.com/watch?v=UK1TWsMLp-QKözzététel (access: 28.08.2014).

Czakó, E. (2006). Tehetséggondozás az egyetemi oktatás hagyományos keretei között). Magyar Tudomány, 2, 230-234.

Czeizel, E. (2004). Sors és tehetség. Budapest: Urbis Könyvkiadó.

Cziráki, Sz. (2015). Tehetségmenedzsment, kulcsemberprogramok, vezetői utánpótlás. In: G. Szakács \& Sz. Szabó (eds.), Közszolgálati HR-menedzsment. Budapest: Nemzeti Közszolgálati Egyetem, 116-122.

Cziráki Sz. \& Szendrő, P. (2016). Nézd más szemmel a világot! A sikeres XXXII. Országos Tudományos Diákköri Konferencia, 2015.) In: Magyar Tudomány, 3, Budapest: Magyar Tudományos Akadémia, 357-363.

Delivering on the Modernization Agenda for Universities: Education, Research and Innovation (2006). Brussels: European Communities.

Derecskei, A. (2012). Keativitás és innováció). In: B. Hámori \& K. Szabó (eds.), Innovációs verseny - esélyek és korlátok. Budapest: Aula Kiadó, 267-297.

Drucker, P. (1969). The Age of Discontinuity. Guidelines to Our Changing Society.

New York: Harper and Row.

Fromm, E. (1993). A szeretet müvészete. Budapest: Háttér Kiadó. 
George, D. (2007). Market overreach: The student as customer. The Journal of Socio-Economics, 36, 965-977.

Hersey, P., Blanchard, K.B. \& Johnson, D.E. (1996). Management of organizational behavior. Utilizing human resources, 7th ed. Upper Saddle River, NJ: Prentice Hall, rove.nla.gov.au/work/10679962?q\&sort=holdingstdesc\&_=1498891196177\&versionId=49071869 (access: 28.08 .2014 ).

Kolnhofer-Derecskei, A. (2016). How do leadership styles influence the creativity of employees? Társadalom és Gazdaság Közép és Kelet Európában - Society and economy in Central and Eastern Europe, 38(1), 103-118.

Konczosné Szombathelyi, M. (2012). Tehetségmenedzsment, avagy a HR felelőssége. In: P. Róbert (ed.), Gazdaság és morál: tiszta társadalom, tiszta gazdaság: a 2012. június 12-i Kautz Gyula Emlékkonferencia válogatott tanulmányai. Konferencia helye, ideje: Győr, Magyarország, 2012.06.12 Győr: Széchenyi István Egyetem Kautz Gyula Gazdaságtudományi Kar, 2013. Paper Online.

Konczosné Szombathelyi, M. (2014). Tehetségés motivációs modell kidolgozásának kérdései a Tudományos és Múvészeti Diákkör kapcsán. In: A. Mészáros (ed.), A felsôoktatás tudományos módszertani és munkaerôpiaci kihívásai a XXI. században. Győr: Széchenyi István Egyetem, 68-81.

Koósné Török, E. \& Baranyainé Réti, G. (eds.) (2008). A TDK kézikönyve. Budapest: Oktatáskutató és Fejlesztő Intézet Országos Tudományos Diákköri Tanács Titkársága.

Kránitz, É. (2012). Tehetségmenedzsment: aktuális kihívások. Human Resources Magazin, IV(1), 34-36.

Lőre, V. \& Bencsik, A. (2008). The role of education system in knowledge transfer among young people. Problems of Education in the 21st Century, $6,136-144$.

Lyceum (classical) (é.n.): Wikipedia. https://hu.wikipedia.org/wiki/L\%C3\%BCkeion (access: 22.06.2017).

Renzulli, J.S. (1977): The Enrichment Triad Model. Wethersfield, CT: Creative Learning Press.

Takács-György, K. \& Takács, I. (2012). Students' research societies as tools of talent management. Problems Of Education In The 21st Century, 42, 115-124.

Takács, I., Takács, E., Baranyai, Zs. \& Takács-György, K. (2009). Talent management in Hungarian higher education. Wspótczesne Zarzadzanie: Kwartalnik Środowisk Naukowych i Liderów Biznesu / International Journal Of Contemporary Management, 4, 73-90.

Takács, I. \& Takácsné György. K. (2010). Tehetséggondozás a magyar felsőoktatásban. Magyar Tudomány, 171(2), 236-245. 
Tóth, T. (ed.) (2001). Az európai egyetem funkcióváltozásai. Felsőoktatás-történeti Tanulmányok. 247 p. Budapest: Professzorok Háza, (Magyar Felsőoktatás Könyvek; 18).

Weiszburg, T. (2008). Tehetséggondozás a felsőoktatásban. Magyar Tudomány, 169(8), 998-1002.

Zhang, X. (2007). Re-examining the mission of the university in mass higher education. Frontiers of Education in China, 2(3), 378-393. 


\title{
ZARZĄDZANIE TALENTAMI W SZKOLNICTWIE WYŻSZYM - STUDIUM PRZYPADKU Z WĘGIER
}

\begin{abstract}
Abstrakt
Tło badań. Na temat roli szkolnictwa wyższego podejmuje się wiele dyskusji. Często autorzy zgadzają się co do ważności zarządzania talentami. Doświadczenia zdobyte podczas studiów są kluczowymi czynnikami dla młodego pokolenia. Coraz większe znaczenie przypisuje się indywidualnemu rozwojowi pracowników.

W nowoczesnych, rozwiniętych (odnoszących sukcesy) gospodarkach większy udział wartości dodanej przywiązuje się do wiedzy (nie do zmaterializowanych zasobów lub kapitału), więc „ludzie są głównym źródłem”. Zmiany w paradygmacie wzięły górę nad przywództwem: liderzy muszą posiadać umiejętności rozwiązywania problemów. Zarządzanie talentami jest jednym z zadań szkolnictwa wyższego.
\end{abstract}

Cel badań. Celem tego badania jest pokazanie, w jaki sposób szkolnictwo wyższe może sprostać oczekiwaniom organizacji w kontekście gospodarki opartej na wiedzy, przy wspieraniu pracy naukowej studentów.

Metodologia. Studium przypadku Studencko-Naukowego Towarzystwa Badawczego.

Kluczowe wnioski. Na podstawie studium przypadku Studencko-Naukowego Towarzystwa Badawczego stwierdzono, że oprócz dobrych prac badawczych istotna jest wiara studentów w to, że są najlepsi.

Słowa kluczowe: talent, wiedza, potrzeby, organizacja, studenckie badania, ruch węgierski. 